\title{
Article/Artigo
}

\section{Frequency of metabolic syndrome and the food intake patterns in adults living in a rural area of Brazil}

\author{
Frequência de síndrome metabólica e padrão de ingestão alimentar de adultos vivendo em \\ uma área rural do Brasil
}

\author{
Karine Fedrigo Silva ${ }^{1}$, Aluízio Prata $\uparrow$ and Daniel Ferreira da Cunha ${ }^{1}$
}

\begin{abstract}
Introduction: Metabolic syndrome (MetS), a risk factor for atherosclerosis and coronary heart disease, is related to an inadequate food intake pattern. Its incidence is increasing among Brazilian adults, including those living in rural areas. Our aim was not only to describe the frequency of MetS in adults with or without MetS but also to compare their food intake pattern as assessed by the healthy eating index (HEI) and serum albumin and $\mathrm{C}$ reactive protein (CRP) levels. Methods: Men and women $(\mathrm{n}=246)$ living in a small village in Brazil were included. MetS was characterized according to the adult treatment panel (ATP III) criteria. Groups were compared by chi-square, student $t$ or Mann-Whitney tests. Results: MetS was diagnosed in $15.4 \%$ of the cases. The MetS group showed higher CRP $(1.8 \pm 1.2$ vs. $1.0 \pm 0.9 \mathrm{mg} / \mathrm{dl})$ and lower albumin $(4.3 \pm 0.3$ vs. $4.4 \pm 0.3 \mathrm{~g} / \mathrm{dl})$ serum levels compared to the control group. Additionally, the MetS group showed lower scores (median[range]) in the HEI compared to the control group (53.5[31.2-78.1] vs 58[29.7-89.5], respectively). The MetS group also had decreased scores for total fat and daily variety of food intake. Conclusions: The results suggest that adults with MetS displayed chronic mild inflammation and a poorer food intake pattern than the control group.
\end{abstract}

Keywords: Metabolic syndrome. Diet Quality. Healthy eating index. Inflammation.

\section{RESUMO}

Introdução: A síndrome metabólica (SM), fator de risco para aterosclerose e cardiopatia isquêmica, está relacionada a uma alimentação inadequada, e sua incidência está aumentando no Brasil, incluindo entre populações rurais. O objetivo deste estudo foi descrever a frequência de síndrome metabólica, e comparar o padrão de ingestão alimentar, avaliado pelo índice de alimentação saudável (healthy eating index - HEI), e níveis séricos de albumina e proteina $\mathrm{C}$ reativa (PCR) entre adultos com ou sem SM. Métodos: Homens e mulheres $(\mathrm{n}=246)$ morando em Inhaumas, pequeno vilarejo do interior da Bahia foram incluídos. SM foi caracterizada de acordo com os critérios do adult treatment panel (ATP III). Os grupos foram comparados pelos testes qui-quadrado, teste $t$ de student ou Mann-Whitney. Resultados: SM foi diagnosticada em $15,4 \%$ dos casos. O grupo SM mostrou maiores níveis séricos de PCR (1.8 \pm 1.2 vs. $1.0 \pm 0.9 \mathrm{mg} /$ $\mathrm{dl})$ e menores valores de albumina ( $4.3 \pm 0.3$ vs. $4.4 \pm 0.3 \mathrm{~g} / \mathrm{dl})$. O grupo SM apresentou menores notas (mediana [faixa de variação]) do HEI (53.5 [31.2-78.1] vs 58[29.7-89.5]), com menores notas para a ingestão de gordura total e variedade de alimentos ingeridos. Conclusões: Adultos com SM mostraram resultados compatíveis com diagnóstico de inflamação crônica, e um padrão de ingestão alimentar inadequado em relação ao controle.

Palavras-chaves: Síndrome metabólica. Qualidade da dieta. Índice de alimentação saudável. Inflamação.

1. Disciplina de Nutrologia, Departamento de Clínica Médica, Universidade Federal do Triângulo Mineiro, Uberaba, MG. † in memorian.

Address to: Dr. Daniel Ferreira da Cunha. Disciplina de Nutrologia/Dept ${ }^{\circ}$ de Clínica Médica/UFTM. Av. Getúlio Guaritá 130, 38025-440 Uberaba, MG, Brasil.

Phone/fax: $55343318-5335$

e-mail: dfnutro@gmail.com

Received in 16/08/2010

Accepted in 13/04/2011

\section{INTRODUCTION}

The main concern in public health nutrition has recently shifted from identifying factors associated with a nutrient deficiency to addressing the consequences of excessive or poorly balanced nutrition. Malnutrition and over nutrition tend to coexist in developing countries that are undergoing a rapid nutritional transition ${ }^{1}$.

Diets that are characterized by a high consumption of fat (energy-dense), especially saturated fat and cholesterol, with a lower contribution of complex carbohydrates and fibers, have been linked to certain chronic, non-communicable diseases including obesity, ischemic heart disease, stroke, high blood pressure and type-2 diabetes mellitus ${ }^{1-3}$.

Metabolic syndrome (MetS) is characterized by abdominal obesity, systemic arterial hypertension, insulin resistance, high serum triglycerides levels and decreased serum HDL-cholesterol. It is associated with a chronic subclinical inflammatory state, as documented by increases in serum C-reactive protein and an increased risk of type 2 diabetes mellitus, atherosclerosis and overall mortality. MetS prevalence is increasing in both developed and developing countries as a result of complex interactions of genetic, metabolic and environmental risk factors, as well as an inadequate food intake pattern ${ }^{4}$.

Lifestyle and diet changes have occurred with industrialization, urbanization, economic development and market globalization. These changes have left a significant impact on the health and nutritional status of a population, particularly in developing countries ${ }^{2}$. Brazil is rapidly shifting from a country with problems of dietary deficits to one of dietary excesses, but regional inequalities still exist. About 20 million Brazilians living in rural areas are progressively adopting a Western dietary pattern and a more sedentary lifestyle ${ }^{5}$.

As income rises in these areas, the food intake pattern changes from a diet based on staples, such as cereal, beans, vegetables, roots and tubers, toward 
one of a higher consumption of meat and processed foods, including refined sugar and vegetable oils $\mathrm{s}^{2,5-8}$.

The healthy eating index (HEI) is a measure of diet quality. It incorporates both nutrient recommendations and dietary guidelines and has been used to assess and monitor overall diet quality, nutrition education, and health promotion ${ }^{1,9}$. Therefore, the aim of this study was to describe the frequency of MetS and to compare the food intake pattern, assessed using the HEI and serum albumin and $\mathrm{C}$ reactive protein (CRP) levels, between adults, with or without MetS, living in a rural area of Brazil.

\section{METHODS}

This cross-sectional study was performed in Inhaumas, a small district of Santa Maria da Vitória, Bahia, Brazil (13 $03^{\circ}$ 04.16" S; $44^{\circ} 37^{\prime} 19.81^{\prime \prime} \mathrm{W}$ ) in 2005 (June, October, and December) and 2006 (April and May). As with other inland small towns with poor infrastructure, people living in Inhaumas have limited access to tap water and inadequate disposal of sewage. They consume a basic diet composed of rice, beans, cassava or corn flour, and soybean oil, plus food produced from traditional subsistence farming.

The sample size was calculated using an estimated prevalence of MetS of $30 \%$ [range: $28-32 \%]^{10}$. The study was approved by the research ethical committee of Universidade Federal do Triângulo Mineiro, City of Uberaba, Brazil, and all participants gave informed consent to participate.

According to the National Cholesterol Education Program Adult Treatment Panel III (NCEP/ATP III), MetS is diagnosed when at least three of the following criteria exist: central obesity, assessed by waist circumference $>102 \mathrm{~cm}$ in men and $>88 \mathrm{~cm}$ in women; systolic blood pressure/diastolic blood pressure $\geq 130 / 85 \mathrm{mmHg}$; fasting glucose $\geq 110 \mathrm{mg} / \mathrm{dL}$; serum triglycerides $\geq 150 \mathrm{mg} / \mathrm{dL}$; and HDL cholesterol $<40 \mathrm{mg} / \mathrm{dL}$ for men and $<50 \mathrm{mg} / \mathrm{dL}$ for women ${ }^{11}$.

Blood pressure was measured by a trained nurse using a mercury sphygmomanometer with the patient in a sitting position after a 5 min rest. People who had blood pressure higher than $130 / 85 \mathrm{mmHg}$ had their blood pressure taken again to make a diagnosis of high blood pressure ${ }^{11}$.

Because of the excellent correlation between capillary blood glucose (measured with the glucose dehydrogenase method) with venous glucose (correlation coefficient of 0.9819 ) ${ }^{12}$, capillary blood glucose concentrations were determined by the Accu-Check Inform System (Accu-Check Advantage ${ }^{\varpi}$-Roche Diagnostics). Blood glucose values higher than $110 \mathrm{mg} / \mathrm{dL}$ were repeated for confirmation ${ }^{11}$. Serum triglycerides and HDL-cholesterol were analyzed enzymatically. Serum urea, creatinine, uric acid and albumin measurements were measured using the Cobas Integra $400^{\circ}$ (Roche Diagnostics). Highsensitivity C-reactive protein, an established marker of low-grade inflammation and a predictor of atherosclerosis, was measured using turbidimetry (Cobas Integra 400 ${ }^{\circledR}$; Roche Diagnostics) ${ }^{13}$.

Anthropometry included weight, height, arm circumference and triceps skin fold determinations. Height was measured without shoes to the nearest $0.1 \mathrm{~cm}$ using a measuring tape. Weight was measured to the nearest $0.1 \mathrm{~kg}$ after voiding, without shoes, and wearing light clothing. Waist circumference was measured at a level midway between the lower costal margin and iliac crest at the end of a normal expiration to the nearest $0.5 \mathrm{~cm}^{14}$. The triceps skin fold was measured on the non-dominant arm using a Holtain ${ }^{\circledR}$ skin fold caliper at a point halfway down the arm between the scapula acromion and the ulna olecranon $^{15}$. Body mass index (BMI) was calculated as weight in kilograms divided by height in square meters $\left(\mathrm{kg} / \mathrm{m}^{2}\right)^{16}$.

Estimates of body fat and lean mass were derived from resistance and reactance measurements with Bioelectrical Impedance Analysis using an RJL Bioelectric Impedance Analyzer (BIA 103-A Detroit, MI, USA).

The $24 \mathrm{~h}$ dietary recall method was performed and an in-depth interview was conducted by a trained dietary interviewer. Information about the subject's total food and drink intake, including quantity and quality of foods, over the past 24 hours period was obtained ${ }^{17,18}$. To accurately estimate the quantity of food, kitchen utensils with pre-established weights including spoons, ladles, cups, skimmers and plates, were used. Data were analyzed using the Virtual Nutri ${ }^{\circledR}$ v.1.5 program (São Paulo, Brazil), a validated software for assessing Brazilian foods and culinary measurements ${ }^{19}$.

The subject's food intake pattern was assessed with the healthy eating index, an indicator of diet quality developed by the US Department of Agriculture to track the quality of the American diet over time and to guide nutrition promotion activities. The HEI has 10 equally weighted components that represent different dietary guidelines in a healthful diet. Components 1 through 5 measure the degree to which an individual diet conforms to the serving recommendations of the USDA Food Guide Pyramid for the five major food groups: grains, vegetables, fruits, dairy and meat. Component 6 measures fat consumption as a percentage of total energy intake. Component 7 is based on consumption of saturated fat as a percentage of total energy intake, and component 8 focuses on cholesterol intake. Component 9 measures sodium intake, and component 10 is based on the variety of foods in a persons's diet. For each component, scores range from 0 to 10 . Individuals with intakes between the minimum and maximum ranges were assigned scores proportionately ${ }^{20}$. Thus, the overall index has a range from 0 to $100^{1}$.

Continuous variables with normal distribution were expressed as the mean \pm standard deviation, and they were compared using the $t$ Student test. The Mann-Whitney test was used for variables with nonnormal distribution, which are expressed as median and range. Fisher's exact test was used to compare frequency distributions between groups. A value $\mathrm{p}<0.05$ was considered statistically significant ${ }^{21}$.

\section{RESULTS}

Of 246 subjects, a total of 38 (15.4\%) MetS cases were diagnosed. Individuals with MetS were older than those without MetS (Table 1). Groups were paired in relation to a male: female ratio, lean body mass measured by bioelectrical impedance analysis, serum urea and uric acid. Individuals with MetS had higher serum creatinine and C-reactive protein and lower serum albumin levels relative to the control group.

As expected, individuals with MetS had higher values for waist circumference, blood pressure levels, serum triglyceride and blood glucose and lower HDL-cholesterol levels relative to the control group. The MetS group also had a higher body weight, body mass index (BMI), triceps skin fold, arm circumference and fat body mass (Table1).

Table 2 displays the median and range of the diet servings ingested per day, contrasting both groups. It also displays the amount of total and saturated fat (\%), daily cholesterol and sodium intake $(\mathrm{mg})$, and variety of food consumed per day. 


\begin{tabular}{|c|c|c|}
\hline & $\begin{array}{c}\text { Control } \\
\text { group }(n=208)\end{array}$ & $\begin{array}{c}\text { Metabolic syndrome } \\
\text { group }(\mathrm{n}=38)\end{array}$ \\
\hline Age $(y)^{*}$ & $40.1 \pm 16.1$ & $56.1 \pm 15.7$ \\
\hline Male: female ratio & $80: 128$ & $11: 27$ \\
\hline Body weight $(\mathrm{kg})^{*}$ & $56.4 \pm 8.6$ & $63 \pm 9.2$ \\
\hline $\operatorname{BMI}\left(\mathrm{kg} / \mathrm{m}^{2}\right)^{*}$ & $22.7 \pm 2.9$ & $25.9 \pm 3.4$ \\
\hline Arm circumference $(\mathrm{cm})^{*}$ & $26.9 \pm 2.8$ & $28.9 \pm 3.2$ \\
\hline Triceps skinfold $(\mathrm{mm})^{*}$ & $13.8 \pm 6.9$ & $17.9 \pm 7.9$ \\
\hline Lean body mass (kg; analyzed by BIA) & $43.5 \pm 8.3$ & $42.1 \pm 9.5$ \\
\hline Fat body mass (kg; analyzed by BIA)* & $12.8 \pm 6.7$ & $20.8 \pm 9.2$ \\
\hline Waist circumference $(\mathrm{cm})^{*}$ & $79.4 \pm 9$ & $91.5 \pm 10.4$ \\
\hline High blood pressure $(\% ; n)^{*}$ & $23.6(49)$ & $78.9(30)$ \\
\hline Serum triglyceride $(\mathrm{mg} / \mathrm{dL})^{*}$ & $119.2 \pm 55.5$ & $209.8 \pm 73.7$ \\
\hline Serum HDL-cholesterol $(\mathrm{mg} / \mathrm{dL})^{*}$ & $39.6 \pm 16.2$ & $28.7 \pm 8.5$ \\
\hline Blood glucose $(\mathrm{mg} / \mathrm{dL})^{*}$ & $87.6 \pm 9.3$ & $95.4 \pm 8.4$ \\
\hline Serum urea $(\mathrm{mg} / \mathrm{dL})$ & $23.6 \pm 7.9$ & $24.7 \pm 8.7$ \\
\hline Serum creatinine $(\mathrm{mg} / \mathrm{dL})^{*}$ & $0.8 \pm 0.2$ & $0.9 \pm 0.3$ \\
\hline Serum uric acid $(\mathrm{mg} / \mathrm{dL})$ & $4.1 \pm 1.3$ & $4.3 \pm 0.9$ \\
\hline Serum albumin $(\mathrm{g} / \mathrm{dL})^{*}$ & $4.4 \pm 0.3$ & $4.3 \pm 0.3$ \\
\hline Serum C-reactive protein $(\mathrm{mg} / \mathrm{dL})^{*}$ & $1.0 \pm 0.9$ & $1.8 \pm 1.2$ \\
\hline
\end{tabular}

TABLE 2 - Number of servings, amount of total and saturated fat, cholesterol and sodium intake and amount of food consumed on a daily basis by the control or metabolic syndrome groups in Inhaúmas, State of Bahia, Brazil, 2006.

\begin{tabular}{lccc}
\hline & $\begin{array}{c}\text { Control } \\
\text { group }(\mathbf{n}=\mathbf{2 0 8})\end{array}$ & $\begin{array}{c}\text { Metabolic syndrome } \\
\text { group }(\mathbf{n}=\mathbf{3 8})\end{array}$ & Criteria for score of 10 \\
\hline Grains & $4.1(0.4-13.7)$ & $3.4(0.7-9.1)$ & 6-11 servings \\
\hline Vegetables* & $0(0-8.6)$ & $0(0-4.2)$ & $2-4$ servings \\
\hline Fruits* & $0(0-5.6)$ & $0(0-2.9)$ & $3-5$ servings \\
\hline Milk and dairy products & $0(0-3.8)$ & $0(0-2.2)$ & $2-3$ servings \\
\hline Meat* & $0.75(0-3.5)$ & $0.44(0-2.2)$ & $2-3$ servings \\
\hline Total fat* & $33.0(13.8-94.4)$ & $38.4(21.3-61.8)$ & $30 \%$ or less energy from fat \\
\hline Saturated fat* & $6.8(1.8-15.1)$ & $7.5(3.1-18.5)$ & $10 \%$ or less energy from fat \\
\hline Cholesterol & $74.4(3-555.2)$ & $64.0(3-321.5)$ & 300 mg or less \\
\hline Sodium & $759.6(16.6-4248.9)$ & $648.1(63.6-2670.9)$ & 2,400 mg or less \\
\hline Variety* & $7(3-16)$ & $6(3-11)$ & 8 or more different types of foods in a day \\
\hline${ }^{*}$ p $<0.05$ & & &
\end{tabular}

TABLE 3 -Scores of healthy eating index (HEI) components of the control or metabolic syndrome groups living in Inhaúmas, State of Bahia, Brazil, 2006.

\begin{tabular}{lcc}
\hline & $\begin{array}{c}\text { Control } \\
\text { group }(\mathbf{n}=\mathbf{2 0 8})\end{array}$ & $\begin{array}{c}\text { Metabolic syndrome } \\
\text { group }(\mathbf{n}=\mathbf{3 8})\end{array}$ \\
\hline Grains & $6.6(0.7-10)$ & $5.7(1.2-10)$ \\
\hline Vegetables & $0(0-10)$ & $0(0-10)$ \\
\hline Fruits & $0(0-10)$ & $0(0-10)$ \\
\hline Milk & $0(0-10)$ & $0(0-8.8)$ \\
\hline Meat & $3.7(0-10)$ & $2.2(0-10)$ \\
\hline Total fat* & $7.4(0-10)$ & $4.4(0-10)$ \\
\hline Saturated fat & $10(0-10)$ & $10(0-10)$ \\
\hline Cholesterol & $10(0-10)$ & $10(0-10)$ \\
\hline Sodium & $10(0-10)$ & $6(0-10)$ \\
\hline Variety* & $8(0-10)$ & \\
\hline Total ${ }^{*}$ & $\mathbf{5 8 . 0}(\mathbf{2 9 . 7 - 8 9 . 5 )}$ & $\mathbf{5 3 . 5 ( 3 1 . 2 - 7 8 . 1 )}$ \\
\hline${ }^{*}$ p $<0.05$. & &
\end{tabular}

The mean HEI score for both groups was 56.9 (range: 12-99). The best scores in the control or metabolic syndrome groups were for saturated fat, cholesterol, and sodium consumption. Mean component scores were the lowest for vegetables, fruits, and milk and dairy products. In relation to the metabolic syndrome group, individuals in the control group had higher scores for total fat consumption and variety of daily food consumption (Table 3 ).

\section{DISCUSSION}

The frequency of MetS was $15.4 \%$ among adults living in this rural Brazilian community, with a similar percentage of cases in women (17.5\%) and men (11.9\%). Despite the fact that a universally accepted definition of MetS is needed for clinical and populationbased studies, the NCEP-ATP III has been used extensively and helps to predict risks of diabetes mellitus and cardiovascular diseases. Moreover, a recent study of people living in Korea showed a very 
high correlation between the International Diabetes Federation and ATP-III definitions ${ }^{22}$.

There are few studies on the prevalence of MetS among people living in rural areas of the world. In a small village of Tyungyulyu (Russia), the prevalence of MetS was 10\% (8\% of males and $12 \%$ of females $)^{23}$. Preliminary results of a study of cardiovascular and metabolic risk factors being conducted in the rural area of Korea showed a prevalence of MetS of 38.6\% (36.6\% of males and 40\% of females, $\mathrm{p}=0.20)^{24}$. In the United States, the Bogalusa Heart Study (1995-1996) conducted in the semi-rural community of New Orleans showed an overall occurrence of MetS in young adults of $12.2 \%(14.9 \% \text { of males and } 10.4 \% \text { of females })^{25}$.

The prevalence of MetS in Brazil varies from 15.8\% among young adults living in Vitoria City, State of Espírito Santo, to $21.6 \%$ in Virgem das Graças, a rural community in the Jequitinhonha Valley, State of Minas Gerais ${ }^{26}$, to $30 \%$ among adults living in rural areas of de Bahia $^{27}$, to $47.4 \%$ among Japanese-Brazilian men living in Bauru, a city located in the mid-western region of the State of São Paulo ${ }^{28}$.

Similar to the research of Salaroli et al.,which studied MetS in urban settings in $\mathrm{Brazil}^{29}$, our results show that in males, the most frequent trait of MetS was high blood pressure followed by hypertriglyceridemia and low HDL-c levels. In the present study, results show that in females, the most frequent MetS criterion were low serum HDL-c levels, hypertriglyceridemia, and abdominal obesity. It is noteworthy that, despite a high prevalence of HBP (high blood pressure) in both groups, the MetS and control groups had a similar low daily intake of sodium. However, this may be because the HEI method considers only the intrinsic sodium content in food.

As in other studies that document the presence of chronic mild inflammation in obesity ${ }^{30}$ and metabolic syndrome ${ }^{31}$, adults with MetS showed increased C-reactive protein and lower albumin serum levels than the control group members. In the MetS group, the increased serum CRP levels are due to higher levels of proinflammatory chemokines and cytokines, which are related to systemic and vascular low-grade inflammation and associated with abdominal obesity. This low-grade vascular inflammation is considered a marker of endothelial dysfunction ${ }^{31}$.

The lower serum albumin levels in the MetS group are not readily understood. A chronic low-grade albuminuria has been noted in patients with MetS without diabetes mellitus ${ }^{32,33}$, which could explain the lower albumin serum levels in patients with MetS. These lower serum albumin levels could also be due to decreased hepatic albumin synthesis or to increased albumin catabolism associated with chronic inflammation ${ }^{34}$. Moreover because systemic endothelial dysfunction is a destructive element of metabolic syndrome ${ }^{35}$, one could conjecture a role for enhanced endothelial permeability allowing for increased albumin passage from the vascular into extravascular space to explain these findings.

Both groups (with or without MetS) had low scores for the consumption of vegetables, fruits, milk and dairy products. The MetS group had lower overall median scores relative to the control group ( 53.5 vs 58 ). These low scores were mainly driven by excessive total fat intake and a low variety of daily food consumption.

The HEI was proposed by Kennedy et al. as a single summary measurement of the dietary quality of the American population. Nutrient intake scores obtained by the HEI correlate very well with biomarkers of fruits and vegetables intake ${ }^{36}$. In addition to the mean
HEI score of 63.9 found by Kennedy et al. in their original work, other studies have found mean scores around $60.1^{37}$, with lower scores for total fat and food variety. The HEI was also applied by Fisberg et al. in a cross-sectional study of 3,454 adults living in large or medium sized cities in the State of São Paulo. This group found a mean HEI score of 60.4, with the lowest scores for vegetables, fruits, and dairy products consumption ${ }^{38}$.

Our findings are not surprising. In Brazil, approximately 44 million people are threatened by hunger and many receive governmental funds (Fome Zero) to buy inexpensive food such as vegetable oils and starchy food. Those living in remote rural areas seem to have few food options because fruits and vegetables are locally scarce most of the year.

Dietary guidelines for the Brazilian population give equal priority to the prevention and control of nutrition deficiencies, food-related transmissible diseases and non-communicable chronic diseases. The findings of this study should be confirmed by studies conducted in other regions of Brazil. Nonetheless, our findings suggest that Brazilian guidelines should also include child and adult dietary education and promotion of a healthy lifestyle and behavior. Special emphasis should be given to individuals with MetS.

\section{CONFLICT OF INTEREST}

The authors declare that there is no conflict of interest.

\section{FINANCIAL SUPPORT}

Supported by FAPEMIG Fundação de Amparo à Pesquisa do Estado de Minas Gerais and CNPq Conselho Nacional de Pesquisa.

\section{REFERENCES}

1. Kennedy ET, Ohls J, Carlson S, Fleming K. The Healthy Eating Index: design and applications. J Am Diet Assoc 1995; 95:1103-1108.

2. World Health Organization. Diet nutrition and prevention of chronic diseases: report of a joint WHO/FAO expert consultation. Geneva: World Health Organization. 2003 Report No: 916. [cited 2005 may 20]. Available from www. who.int/hpr/.

3. Guo X, Wardem BA, Paeratakul S, Bray GA. Healthy eating index and obesity. Eur J Clin Nutr 2004; 58:1580-1586.

4. Reaven GM. Insulin resistance, the insulin resistance syndrome, and cardiovascular disease. Panminerva Med 2005; 47:201-210.

5. Monteiro CA, Mondini L, Souza AL, Popkin BM. The nutrition transition in Brazil. Eur J Clin Nutr 1995; 49:105-113.

6. Cannon G. Diet-related chronic diseases. In: Flores R, Gillespie S, editors. Vision for food, agriculture and the environment. Health and nutrition. Emerging and remerging issues in developing countries: policy briefs. Washington: International Food Policy Research Institute; 2001. p. 16-17.

7. Lang T, Mcmichael A. The public health impact of globalization of food trade. In: Shetty P, Mcpherson K, editors. Diet, Nutrition and Chronic Disease: lessons from contrasting worlds. London School of Hygiene and Tropical Medicine Sixth Annual Public Health Forum. Chichester: John Wiley; 1997. p. 210-250.

8. Cannon G. Food and health: the experts Agree. London: Consumers Association; 1992.

9. Basiotis PP, Carlson A, Gerrior SA, Juan WY. The healthy eating index: 19992000. Washington (U.S): Department of Agriculture, Center for Nutrition Policy and Promotion; 2002.

10. Meigs JB. Epidemiology of the metabolic syndrome, 2002. Am J Manag Care 2002; 8: S283-S292. 
11. National Institutes of Health. Executive summary of the third report of the National Cholesterol Education Program Expert Panel on Detection, Evaluation, and Treatment of High Blood Cholesterol in Adults (Adult Treatment Panel III). Jama 2001; 285:2486-2497.

12. Mira GS, Candido LMB, Yale JF. Performance de glicosímetro utilizado no automonitoramento glicêmico de portadores de diabetes mellitus tipo 1 . Arq Bras Endocrinol Metab 2006; 50:541-549.

13. Bassuk SS, Rifai N, Ridker PM. High-sensitivy C-reactive protein: clinical importance. Curr Probl Cardiol 2004; 29:439-493.

14. Lean MEJ, Han TS, Morrison CE. Waist circumference as a measure for indicating need for weight management. BMJ 1995; 311:158-161.

15. Jelliffe DB. The assessment of the nutritional status of the community (with special reference to field surveys in developing regions of the world) Monogr Ser World Health Organ 1966; 53:3-271.

16. Buchholz AC, Bugaresti JM. A review of body mass index and waist circumference as markers of obesity and coronary heart disease risk in persons with chronic spinal cord injury. Spinal Cord 2005; 43:513-518.

17. Willett W. Nutritional epidemiology. $2^{\text {nd }}$ ed. Boston: Oxford University Press; 1998.

18. Hatzis CM, Bertsias GK, Linardakis M, Scott JM, Kafatos AG. Dietary other lifestyle correlates of serum folate concentrations in a healthy adult population in Crete, Greece: a cross-sectional study. Nutr J 2006; 5:5.

19. Dias CG, Ribeiro AG, Scabim VM, Faintuch J, Zilberstein B, Gama-Rodrigues JJ Dietary intake of female bariatric patients after anti-obesity gastroplasty. Clinics 2006; 61:93-98.

20. Bowman SA, Linn M, Gerrior SA, Basiotis PP. The Healthy Eating Index, 1994-96. Washington, DC: US Department of Agriculture;1998.

21. Noether GE. Introdução à estatística: uma abordagem não paramétrica. São Paulo: Editora Guanabara; 1983.

22. Sung KC, Kim BJ, Kim BS, Lee WY, Park JB, Wilson AM. A comparison of the prevalence of the MS and its complications using three proposed definitions in Korean subjects. Am J Cardiol 2009; 103:1732-1735

23. Snodgrass JJ, Leonard WR, Tarskaia LA, Egorova AG, Maharova NV, Pinigina IA, et al. Impaired fasting glucose and metabolic syndrome in an indigenous Siberian population. Int J Circumpolar Health 2010; 69:87-98.

24. Ahn MS, Kim JY, Youn YJ, Kim SY, Koh SB, Lee K, et al. Cardiovascular Parameters Correlated with Metabolic Syndrome in a Rural Community Cohort of Korea: The ARIRANG Study. J Korean Med Sci 2010; 25:1045-1052.

25. Deshmukh-Taskar PR, O’Neil CE, Nicklas TA, Yang SJ, Liu Y, Gustat J, et al. Dietary patterns associated with metabolic syndrome, sociodemographic and lifestyle factors in young adults: the Bogalusa Heart Study. Public Health Nutr 2009; 12:2493-2503.

26. Velásquez-Meléndez G, Gazzinelli A, Côrrea-Oliveira R, Pimenta AM, Kac G. Prevalence of metabolic syndrome in a rural area of Brazil. São Paulo Med J 2007; 125:155-162.

27. Oliveira EP, Souza MLA, Lima MDA. Prevalência de síndrome metabólica em uma área rural do semi-árido baiano. Arq Bras Endocrinol Metab 2006; 50:456-465

28. Rosenbaum P, Gimeno SG, Sanudo A, Franco LJ, Ferreira SR. Japanese-Brazilian diabetes study group. Analysis of criteria for metabolic syndrome in a populationbased study of Japanese-Brazilians. Diabetes Obes Metab 2005; 7:352-359.

29. Salaroli LB, Barbosa GC, Mill JG, Molina MC. Prevalence of metabolic syndrome in population-based study, Vitória, ES - Brazil. Arq Bras Endocrinol Metabol 2007; 51: 1143-1152.

30. Nakanishi N, Shiraishi T, Wada M. Association between C-reactive protein and insulin resistance in a Japanese population: the Minoh Study. Intern Med 2005 ; 44:542-547.

31. Duncan BB, Schmidt MI. Chronic activation of the innate immune system may underlie the metabolic syndrome. São Paulo Med J 2001; 119:122-127.

32. Solbu MD, Kronborg J, Jenssen TG, Njolstad I, Lochen ML, Mathiesen EB, et al. Albuminuria, metabolic syndrome and the risk of mortality and cardiovascular events. Atherosclerosis 2009; 204:503-508.
33. Chen B, Yang D, Chen Y, Xu W, Ye B, Ni Z. The prevalence microalbuminuria and its relationships with the components of metabolic syndrome in the general population of China. Clin Chim Acta 2010; 411:705-709.

34. Cunha DF, Monteiro JP, Vitorino MS, Oliveira FA, Cunha SFC. Hyponatremia in acute-phase response syndrome patients in general surgical wards. Am J Nephrol $2000 ; 20: 37-41$.

35. Temm C, Dominguez JH. Microcirculation: nexus of comorbidities in diabetes. Am J Physiol Renal Physiol 2007; 293:486-493.

36. Weinstein SJ, Vogt TM, Gerrior SA. Healthy Eating Index scores are associated with blood nutrient concentrations in the Third Health and Nutrition Examination Survey. J Am Diet Assoc 2004; 104:576-584.

37. McCabe-Sellers BJ, Bowman S, StuffJE, Champagne CM, Simpson PM, Bogle ML. Assessment of the diet quality of US adults in the Lower Mississippi Delta. Am J Clin Nutr 2007; 86:697-706.

38. Fisberg RM, Morimoto JM, Slater B, Barros MB, Carandina L, Godbaum M et al. Dietary quality and associated factors among adults living in the state of São Paulo, Brazil. J Am Diet Assoc 2006; 106:2067-2072. 